Vandecasteele B., Meers E., Vervaeke P., Vos B.D., Quataert P., Tack F.M.G., 2005. Growth and trace metal accumulation of two Salix clones on sediment-derived soils with increasing contamination levels. Chemosphere 58 (8), 995-1002.

The original publication is available at http://www.elsevier.com/

\title{
GROWTH AND TRACE METAL ACCUMULATION OF TWO SALIX CLONES ON SEDIMENT-DERIVED SOILS WITH INCREASING CONTAMINATION LEVELS
}

\author{
Bart Vandecasteele ${ }^{1, *}$, Erik Meers ${ }^{2}$, Pieter Vervaeke ${ }^{2}$, Bruno De Vos ${ }^{1}$, Paul Quataert ${ }^{1}$, Filip \\ M.G. Tack ${ }^{2}$ \\ ${ }^{1}$ Institute for Forestry and Game Management, Ministry of the Flemish Community, \\ Gaverstraat 4, B-9500 Geraardsbergen, Belgium \\ ${ }^{2}$ Ghent University, Department of Applied Analytical and Physical Chemistry, Coupure 653, \\ B-9000 Ghent, Belgium
}

* Correspondence: B. Vandecasteele. E-mail: Bart.Vandecasteele@lin.vlaanderen.be, Tel. + 3254436168, Fax. + 3254436160

Key words: phytoremediation, willows, contaminated sediment, dredged, bioavailability

\section{Abstract}

The growth and metal uptake of two willow clones (Salix fragilis 'Belgisch Rood' and Salix viminalis 'Aage') was evaluated in a greenhouse pot experiment with 6 sedimentderived soils with increasing field Cd levels $\left(0.9-41.4 \mathrm{mg} \mathrm{kg}^{-1}\right)$. Metal concentrations of 8 elements were measured in roots, stems and leaves and correlated to total and soil water metal concentrations. Dry weight root biomass, number of leaves and shoot length were measured to identify eventual negative responses of the trees.

No growth inhibition was observed for both clones in all treatments (max. $41.4 \mathrm{mg} \mathrm{kg}^{-1}$ $\mathrm{Cd}, 1914 \mathrm{mg} \mathrm{kg}^{-1} \mathrm{Cr}, 2422 \mathrm{mg} \mathrm{kg}^{-1} \mathrm{Zn}, 655 \mathrm{mg} \mathrm{kg}^{-1} \mathrm{~Pb}$ ), allowing their use for phytoextraction on a broad range of contaminated sediments. However, dry weight root biomass and total shoot length were significantly lower for $S$. viminalis compared to $S$. fragilis for all treatments.

Willow foliar Cd concentrations were strongly correlated with soil and soil water $\mathrm{Cd}$ concentrations. Both clones exhibited high accumulation levels of $\mathrm{Cd}$ and $\mathrm{Zn}$ in aboveground plant parts, making them suitable subjects for phytoextraction research. $\mathrm{Cu}, \mathrm{Cr}, \mathrm{Pb}, \mathrm{Fe}, \mathrm{Mn}$ 
and $\mathrm{Ni}$ were found mainly in the roots. Bioconcentration factors of $\mathrm{Cd}$ and $\mathrm{Zn}$ in the leaves were highest for the treatments with the lowest soil $\mathrm{Cd}$ and $\mathrm{Zn}$ concentration.

\section{Introduction}

Several studies have shown that many species or clones of Salix have the capacity to accumulate high levels of $\mathrm{Cd}$ in aboveground biomass compartments (Landberg and Greger, 1994; Landberg and Greger, 1996; Felix, 1997; Lunácková et al., 2003; Roselli et al., 2003; Vandecasteele et al., 2004). Salix trees on calcareous metal contaminated sites can thus mobilize Cd from the subsoil and recycle it to the stand surface with leaf fall (Beyer et al., 1990). This raises concerns of increased Cd mobility in natural ecosystems and the risk of food chain contamination. Conversely, this also opens prospects of cleaning Cd contaminated soils through repeated harvesting of the produced wood and leaf biomass in carefully managed and monitored short rotation forestry systems (Östman, 1994).

Dredged sediment is a highly suitable substrate for willow growth (Vervaeke et al., 2001). Salix is an early colonizer of contaminated dredged sediment-derived soils (Vandecasteele et al., 2002b). However, due to poor national water management in the past and transboundary industrial fluxes from Northern France, most fine-grained sediments of the Belgian inland waterways contain elevated levels of heavy metals. Vandecasteele et al. (2002b) showed that, on historically polluted dredged-sediment disposal sites, concentrations of $\mathrm{Cd}$ and $\mathrm{Zn}$ in willow leaves increased with levels in the soil. This suggested that foliar $\mathrm{Cd}$ and $\mathrm{Zn}$ concentrations could be a good indicator of $\mathrm{Cd}$ and $\mathrm{Zn}$ availability in contaminated sediment-derived soils. Willows can be easily reproduced with cuttings and grow fast, which makes them well suited for testing metal bioavailability and accumulation.

This paper presents results of a greenhouse study which further investigates this correlation. The aim of this experiment was to determine if metal uptake by 2 willow clones was correlated to the total and soil water metal concentrations over a pollution gradient. The assessment was made for the root, stem, and leaf compartments. Root biomass, number of leaves, and shoot length were determined to identify eventual effects of soil contamination.

\section{Materials and methods}

\subsection{Soil characteristics}

Six sites on sediment-derived soils with a range of $\mathrm{Cd}$ concentrations were selected for sampling (Table 1). On each site, the $0-30 \mathrm{~cm}$ soil horizon was sampled in quadruplicate. Soil material was intensively mixed and homogenized, while stones, plastics and branches if any were removed. Total $\mathrm{Cd}, \mathrm{Cr}, \mathrm{Cu}, \mathrm{Ni}, \mathrm{Pb}, \mathrm{Mn}, \mathrm{Fe}$ and $\mathrm{Zn}$ concentrations were measured in aqua regia extracts on ICP-AES (Varian Liberty Series II, Varian, Palo Alto, CA). Soil $\mathrm{pH}_{\mathrm{H} 2 \mathrm{O}}$, $\mathrm{pH}_{\mathrm{CaCl} 2}$ and electrical conductivity (EC) were measured in a 1:5 soil to water suspension after stirring for $2 \mathrm{~h}$. Organic carbon (OC) was determined by the method of Walkley-Black, assuming that this method measures $75 \%$ of the total organic carbon. $\mathrm{CaCO}_{3}$ content was determined by back-titration with $0.5 \mathrm{M} \mathrm{NaOH}$ of an excess of $\mathrm{H}_{2} \mathrm{SO}_{4}$ added to $1 \mathrm{~g}$ air-dried sediment. The grain size distribution of the soil samples was determined using laser diffractometry (Coulter LS200, Miami, FL) with the clay fraction defined as the 0-6 $\mu \mathrm{m}$ fraction (Vandecasteele et al., 2002a). Total soil $\mathrm{N}$ was measured by a $\mathrm{NH}_{4}-\mathrm{N}$ distillation method and then titrated with boric acid. All soils were characterized as calcareous, fertile, heavy clay soils. 


\subsection{Greenhouse experiment}

Containers (LWH: $11 \times 11 \times 11 \mathrm{~cm}$ ) were filled with $1.4 \mathrm{~kg}$ of each of the 6 soils at field capacity. Twenty cm cuttings of Salix fragilis L. 'Belgisch Rood' and S. viminalis L. 'Aage' were planted in 6 replicates for each soil type. Both clones were selected for their elevated metal uptake. All containers were placed in a greenhouse with regular irrigation to keep the soil at a constant moisture content (approx. 30\%). Each container was fitted with a $10 \mathrm{~cm}$ RhizoMOM soil moisture sampler (Eijkelkamp, Giesbeek, NL) to extract the soil solution. Soil solution was sampled in vacuum tubes after 100 days of plants growth.

Leaves, stems and roots were sampled 100 days after the start of the experiment. For each replicate, the number of leaves, the total shoot length per cutting, the length of the first shoot per cutting, and the dry weight (DW) root biomass were determined. Roots were soaked in water for $24 \mathrm{~h}$ and gently washed with abundant water to remove soil particles. They were subsequently dried for 7 days at $40{ }^{\circ} \mathrm{C}$ and weighed. To assure a sufficient quantity of roots, stems and leaves for tissue analysis, the replicates per clone and per soil type were combined.

\subsection{Chemical analyses of plant compartments and soil solution}

Foliar, stem and root samples were dried for 7 days at $40{ }^{\circ} \mathrm{C}$, mechanically ground (Pulverisette 14, Fritsch, Idar-Oberstein, Germany), and stored in dark vials before analysis. Total element concentrations in roots, stems and leaves are extracted with $\mathrm{HNO}_{3}$ (p.a. 65\%) and $\mathrm{H}_{2} \mathrm{O}_{2}$ (ultrapur) in a 3:1 ratio using microwave digestion and measured with ICP-AES (Varian Liberty Series II, Varian, Palo Alto, CA). The accuracy of the tissue element analysis was checked using BCR 60 (Aquatic plant) for $\mathrm{Cd}, \mathrm{Cu}, \mathrm{Mn}$ and $\mathrm{Zn}$, and CRM 100 (Beech leaves) for $\mathrm{Cr}$.

Soil solution was analyzed for $\mathrm{Cd}, \mathrm{Zn}$, and $\mathrm{Cu}$ using Flame Atomic Absorption Spectrometry (Varian SpectrAA 10) and ET Atomic Absorption Spectrometry with Zeeman correction (Varian SpectrAA 800, Varian, Palo Alto, CA).

\subsection{Statistical analysis}

The metal concentration in the different tissue compartments of the plants was studied by a general linear model with one continuous variable (concentration in the soil) and two factors (clone and tissue compartment). This allowed to test statistically if the relation with the soil concentration depended on clone or tissue compartment. In case of interaction or heteroscedasticity the regression model was fitted to each tissue compartment separately tot study the clone effect. Cd concentrations in plant tissue compartments were square roottransformed prior to analysis to meet the condition of normality and homoscedasticity.

Growth parameters were compared with two-way ANOVA with the factors 'soil and 'clone'. No interaction between 'clone' and 'soil' was observed for any of the growth parameters. Bioconcentration factors (BCF) for $\mathrm{Cd}$ and $\mathrm{Zn}$ on a dry weight (DW) base were defined as the ratio [foliar concentration/total soil concentration (aqua regia)]. Soil pollution levels were assessed according to the criteria outlined by the Flemish Decree on Soil Sanitation (VLAREBO 1996). Exceedances over regulatory levels were calculated after correction was made for soil organic matter content and clay fraction. 


\subsection{Biomass production}

Both of the Salix clones featured comparable root, shoot and leaf production for the 6 treatments, as the soil type did not significantly influence the selected growth parameters (Table 2). No negative effects of the pollution could thus be determined. However, the root biomass production and the total shoot length of the Salix viminalis trees was consistently lower $(\mathrm{p}<0.01)$ compared to the production of Salix fragilis.

\subsection{Metal accumulation}

$\mathrm{Cd}$ concentrations in the soil $\left(\mathrm{Cd}_{\text {soil }}, \mathrm{mg} \mathrm{kg}^{-1}\right.$ dry soil $)$ and in the pore water $\left(\mathrm{Cd}_{\text {pore }}, \mu \mathrm{g}\right.$ $\mathrm{L}^{-1}$ ) had a similar sum of squares in stepwise linear regression and were both suitable for predicting plant tissue concentrations (Fig. 1, Fig. 2). No effect of clone or tissue compartment on $\mathrm{Cd}$ plant concentrations was observed, but tissue concentrations $\left(\mathrm{Cd}_{\text {plant }}\right.$, average concentration in leaves, stems and roots, $\left.\mathrm{mg} \mathrm{kg}^{-1} \mathrm{DW}\right)$ were positively correlated ( $\mathrm{p}<$ 0.001) with soil Cd concentrations (Fig. 1). The linear models were:

$$
\begin{aligned}
& \operatorname{Sqrt}\left(\mathrm{Cd}_{\text {plant }}\right)=2.3+0.112 \mathrm{Cd}_{\text {soil }}\left(\mathrm{R}^{2}=0.815\right) \\
& \operatorname{Sqrt}\left(\mathrm{Cd}_{\text {plant }}\right)=2.4+1.223 \mathrm{Cd}_{\text {pore }}\left(\mathrm{R}^{2}=0.798\right)
\end{aligned}
$$

$\mathrm{Zn}$ concentrations in leaves, stems and roots were positively influenced by $\mathrm{Zn}$ concentrations in the soil (Fig. 1). There was a significant difference $(p=0.006)$ for $\mathrm{Zn}$ between clones, with higher $\mathrm{Zn}$ concentrations for clone "Aage". Highest $\mathrm{Zn}$ concentrations were measured in the roots (Fig. 1), intermediate concentrations were observed in the leaves while lowest concentrations were found in the stems. In contrast to $\mathrm{Cd}, \mathrm{Zn}$ concentration in the pore water could not be used for predicting $\mathrm{Zn}$ concentrations in tissue compartments (Fig. 2). The resulting linear model is:

$$
\mathrm{Zn}_{\text {plant }}=513.4+0.186 \mathrm{Zn}_{\text {soil }}-83.16 \text { clone }-274.97 \text { stem }+169.54 \operatorname{root}\left(\mathrm{R}^{2}=0.849\right)
$$

with $\mathrm{Zn}_{\text {plant }}=\mathrm{Zn}$ concentration $\left(\mathrm{mg} \mathrm{kg}^{-1} \mathrm{DW}\right)$ in leaves $($ stem $=0$, root $=0$ ), stems $($ stem $=1$, root $=0)$ or roots $($ stem $=0$, root $=1)$ for clone Salix fragilis 'Belgisch Rood' (clone $=1$ ) and $S$. viminalis 'Aage' (clone $=0)$.

No effect of clone or soil concentrations was detected for $\mathrm{Fe}, \mathrm{Ni}$ and $\mathrm{Cu}$, but root concentrations were significantly higher $(\mathrm{p}<0.001)$ than foliar and stem concentrations (Fig. 1, Fig. 3, Table 3). Soil (Fig. 1) and pore water (Fig. 2) concentrations did not affect the plant tissue concentrations for $\mathrm{Cu}$. Foliar $\mathrm{Mn}$ concentrations were clearly higher than root and stem concentrations for clone "Belgisch Rood", while root, stem and foliar concentrations were comparable and independent of soil concentrations for clone "Aage" (Fig. 1). No clonal differences were found for $\mathrm{Pb}$ concentrations in any tissue compartment (Fig. 3). Only $\mathrm{Pb}$ concentrations in the roots were positively affected by soil concentrations. Clone and soil $\mathrm{Cr}$ concentrations did not have a significant effect on $\mathrm{Cr}$ concentrations in roots and stems, while foliar $\mathrm{Cr}$ concentrations were significantly higher for clone 'Belgisch Rood' (Fig. 3, Table 3). In general, $\mathrm{Fe}, \mathrm{Cu}, \mathrm{Cr}, \mathrm{Pb}$ and $\mathrm{Ni}$ are not translocated to stems and leaves, while $\mathrm{Zn}$ in both clones and $\mathrm{Mn}$ in clone "Belgisch Rood" is mainly translocated to the leaves. Cd is found in 
comparable concentrations in roots, stems and leaves, with higher plant concentrations for soils with higher $\mathrm{Cd}$ contaminations levels.

It is remarkable that root $\mathrm{Fe}, \mathrm{Ni}, \mathrm{Pb}, \mathrm{Mn}$ and $\mathrm{Cr}$ concentrations were clearly lower compared to the soil concentrations, while root $\mathrm{Cd}, \mathrm{Cu}$, and $\mathrm{Zn}$ concentrations were comparable with soil concentrations (Fig. 1, Fig. 3, Table 3).

Bioconcentration factors $(\mathrm{BCF})$ for $\mathrm{Cd}$ and $\mathrm{Zn}$ in the leaves were substantially higher than 1 for the least contaminated soil, but $\mathrm{BCF}$ for $\mathrm{Zn}$ was lower than 1 for the other tested soils (Fig. 4). BCF for $\mathrm{Cd}$ in the contaminated soils ranged between 0.8 and 1.6 for clone "Belgisch Rood" and between 1.0 and 2.3 for clone "Aage" (Fig. 4).

\section{Discussion}

Relatively high EC values were measured for soil S1, S3 and S5 (Table 1), but values were still in the nonsaline range (Craul, 1992). EC is a measure for soluble salts, e.g. chlorides and sulphates. High concentrations of sodium and chlorides might harm plants. Average $\mathrm{Na}$ concentrations in soils S2, S3, S4 and S5 are 374, 434, 532 and $611 \mathrm{mg} \mathrm{kg}^{-1}$ dry soil, respectively. These concentrations are considered normal (Craul, 1992) and would thus not cause plant growth reduction. During the greenhouse experiment, negative effects of chlorides, such as marginal chlorosis of leaves, were not observed. A more realistic explanation for the high EC values is the formation of sulphates during oxidation of sulphides after landfilling of initially reduced dredged sediments.

Soil metal concentrations were elevated for S2-S6, especially for Cd, Cr and Zn. Soil $\mathrm{Cd}$ concentrations in S2-S6 were above the sanitation standard values for agriculture as outlined by the Flemish Decree on Soil Sanitation (VLAREBO 1996). Cr concentrations exceeded the sanitation standard values for agriculture in S2 and S3, and were in excess of the sanitation standard values for industry in S4, S5 and S6. Zn concentrations exceeded the pollution criterion for $\mathrm{S} 2$ and $\mathrm{S} 3$, and were above the sanitation standard values for recreational areas in S4, S5 and S6.

The results of the greenhouse experiment confirm the conclusions of Punshon and Dickinson (1997), Stoltz and Greger (2002) and Rosselli et al. (2003) that willows are shoot accumulators for $\mathrm{Zn}$ and $\mathrm{Cd}$, and root accumulators for $\mathrm{Cu}, \mathrm{Cr}, \mathrm{Ni}$ and $\mathrm{Pb}$. Generally, the observed aboveground $\mathrm{Cd}$ concentrations $\left(>45 \mathrm{mg} \mathrm{kg}^{-1} \mathrm{DW}\right.$ in roots, stems and leaves for soil S6) were high when compared to levels encountered on dredged sediment disposal sites in field trials with planted (Meers et al., 2003; Vervaeke et al., 2003) or volunteer (Vandecasteele et al., 2002b) willows, but the range of soil concentrations in this study is larger than for previous studies. Meers et al. (2003) reported Cd concentrations of 7.4-9.5 mg $\mathrm{kg}^{-1} \mathrm{DW}$ for three clones of $S$. viminalis for soils with 1.0-5.0 mg Cd kg-1 dry soil. Vervaeke et al. (2003) measured foliar concentrations of $4.3 \mathrm{mg} \mathrm{Cd} \mathrm{kg}^{-1} \mathrm{DW}$ for Salix viminalis 'Orm' on a site with $3.0 \mathrm{mg} \mathrm{Cd} \mathrm{kg}{ }^{-1}$ dry soil. Volunteer willow species on dredged sediment landfills had Cd concentrations in the leaves between 1.1-18.1 $\mathrm{mg} \mathrm{kg}^{-1} \mathrm{DW}$ for soils with $0.5-20 \mathrm{mg} \mathrm{Cd}$ $\mathrm{kg}^{-1}$ dry soil (Vandecasteele et al., 2002b). The clones used in this study were selected for their elevated uptake of $\mathrm{Cd}$ and $\mathrm{Zn}$ and deserve further research for phytoextraction purposes under field conditions.

No field results for clone Aage are available. Planting Salix fragilis 'Belgisch Rood' in a field trial on a slightly contaminated dredged sediment disposal site resulted in elevated wood, bark and foliar concentrations for $\mathrm{Cd}$ and $\mathrm{Zn}$, while $\mathrm{Cr}, \mathrm{Cu}, \mathrm{Ni}$ and $\mathrm{Pb}$ were less easily accumulated in aboveground biomass compartments. Especially for 1 and 2 year old stands, high foliar and bark concentrations were measured, with increasing concentrations during the growing season, exceeding $70 \mathrm{mg} \mathrm{kg}^{-1} \mathrm{DW}$ just before leaf shedding (Vervaeke et al., 2004). 
$\mathrm{Cd}$ and $\mathrm{Zn}$ concentrations in the roots, stems and leaves are clearly elevated for willows grown on S2-S6 when compared with baseline concentrations for willows. Eriksson and Ledin (1999) reported baseline Cd concentrations in leaf samples between 0.31 and 1.96 $\mathrm{mg} \mathrm{kg}{ }^{-1} \mathrm{DW}$ for $S$. viminalis on different non-polluted soils in Sweden. Nissen and Lepp (1997) found $\mathrm{Zn}$ concentrations in several willow species in the UK ranging between 82 and $296 \mathrm{mg} \mathrm{Zn} \mathrm{kg}^{-1} \mathrm{DW}$, while a baseline range of 0.5-2.9 mg Cd kg${ }^{-1} \mathrm{DW}$ and $128-338 \mathrm{mg} \mathrm{Zn} \mathrm{kg}$ ${ }^{1}$ DW was reported by Vandecasteele et al. (2002b).

No detrimental effect of pollution was observed on root biomass and the other growth parameters, although root growth was reported to be a very sensitive indicator for metal toxicity (Kahle, 1993; Landberg and Greger, 2002; Punshon and Dickinson, 1997; Šottníková et al., 2003; Watson et al., 1999).

There was a general positive relation between soil and plant $\mathrm{Cd}$ concentrations. These results confirm the observations for field-collected willow leaves (Vandecasteele et al., $2002 b$ ). For calcareous and clayey sediment-derived soils, both aqua regia extractable soil Cd concentrations and pore water $\mathrm{Cd}$ concentrations are thus a good indicator for prediction of $\mathrm{Cd}$ bioavailability for willows. For $\mathrm{Zn}$, soil type, clone and tissue compartment influenced the result.

Foliar $\mathrm{Cd}$ and $\mathrm{Zn}$ concentrations were clearly higher for the more polluted sedimentderived soils relative to the $\mathrm{S} 1$ soil with the lowest contamination level (Fig. 1). However, $\mathrm{BCF}$ for $\mathrm{Cd}$ and $\mathrm{Zn}$ was highest for the least contaminated soil (Fig. 4). Willows on uncontaminated and slightly contaminated soils typically have high foliar BCF for $\mathrm{Cd}$ and $\mathrm{Zn}$ (Granel et al., 2002; Meers et al., 2003; Rosselli et al., 2003), while lower BCF for Cd and Zn on polluted DSDS were found for several willow species (Vandecasteele et al., 2004). These findings indicate that the use and value of willows for phytoextraction might be restricted to soils where $\mathrm{Cd}$ and $\mathrm{Zn}$ concentrations are only slightly elevated. 


\section{References}

Beyer, W.N., Miller, G., Simmers, J.W., 1990. Trace elements in soil and biota in confined disposal facilities for dredged material. Environ. Pollut. 65, 19-32.

Eriksson, J., Ledin, S., 1999. Changes in phytoavailability and concentration of cadmium in soil following long term Salix cropping. Water Air Soil Pollut. 114, 171-184.

Felix, H., 1997. Field trials for in situ decontamination of heavy metal polluted soils using crops of metal-accumulating plants. Z. Pflanzenernahr. Bodenkd. 160, 525-529.

Granel, T., Robinson, B., Mills, T., Clothier, B., Green, S., Fung, L., 2002. Cadmium accumulation by willow clones used for soil conservation, stock fodder and phytoremediation. Aust. J. Soil Res. 40, 1331-1337.

Kahle, H., 1993. Response of roots of trees to heavy metals. Environ. Exp. Bot. 33, 99-119.

Landberg, T., Greger, M., 1994. Can heavy metal tolerant clones of Salix be used as vegetation filters on heavy metal contaminated land? In: Aronsson, P., Perttu, K. (Eds.). Proceedings of the Conference Willow vegetation filters for municipal wastewaters and sludges: A biological purification system. Sweden, 5-10 June 1994. Swedish University of Agricultural Sciences, Uppsala, Sweden. pp 133-144.

Landberg, T., Greger, M., 1996. Differences in uptake and tolerance to heavy metals in Salix from unpolluted and polluted areas. Appl. Geochem. 11, 175-180.

Landberg, T., Greger, M., 2002. Interclonal variation of heavy metal interactions in Salix viminalis. Environ. Toxicol. Chem. 21, 2669-2674.

Lunácková, L., Masarovicová, E., Kráová, K., Stresko, V., 2003. Response of fast growing woody plants from family Salicaceae to cadmium treatment. Bull. Environ. Contam. Toxicol. 70, 576-585.

Meers, E., Vervaeke, P., Tack, F.M.G., Lust, N., Verloo, M.G., Lesage, E., 2003. Field trial experiment: phytoremediation with Salix sp. on a dredged sediment disposal site in Flanders, Belgium. Remediat. J. 13, 87-97.

Nissen, L.R., Lepp, N.W., 1997. Baseline concentrations of copper and zinc in shoot tissues of a range of Salix species. Biomass Bioenerg. 12, 115-120.

Östman, G., 1994. Cadmium in Salix - a study of the capacity of Salix to remove cadmium from arable soils. In: Aronsson, P., Perttu, K. (Eds.). Proceedings of the Conference Willow vegetation filters for municipal wastewaters and sludges: A biological purification system. Sweden, 5-10 June 1994. Swedish University of Agricultural Sciences, Uppsala, Sweden. pp 153-156.

Punshon, T., Dickinson, N.M., 1997. Acclimation of Salix to metal stress. New Phytol. 137, 303-314.

Rosselli, W., Keller, C., Boschi, K., 2003. Phytoextraction capacity of trees growing on a metal contaminated soil. Plant Soil 256, 265-272. 
Šottníková, A., Lunáčková, L., Masarovičová, E., Lux, A., Streško, V., 2003. Changes in the rooting and growth of willows and poplars induced by cadmium. Biol. Plantarum 46, 129131.

Stoltz, E., Greger, M., 2002. Accumulation properties of As, $\mathrm{Cd}, \mathrm{Cu}, \mathrm{Pb}$ and $\mathrm{Zn}$ by four wetland plant species growing on submerged mine tailings. Environ. Exp. Bot. 47, 271-280.

Vandecasteele, B., De Vos, B., Tack, F.M.G., 2002a. Heavy metal contents in surface soils along the Upper Scheldt river (Belgium) affected by historical upland disposal of dredged materials. Sci. Total Environ. 290, 1-14.

Vandecasteele, B., De Vos, B., Tack, F.M.G., 2002b. Cadmium and Zinc uptake by volunteer willow species and elder rooting in polluted dredged sediment disposal sites. Sci. Total Environ. 299, 191-205.

Vandecasteele, B., Quataert, P., De Vos, B., Tack, F.M.G., Muys, B., 2004. Foliar concentrations of volunteer willows growing on polluted sediment-derived sites versus sites with baseline contamination levels. J. Environ. Monit. 6, 313 - 321.

Vervaeke, P., Luyssaert, S., Mertens, J., De Vos, B., Speleers, L., Lust, N., 2001. Dredged sediment as a substrate for biomass production of willow trees established using the SALIMAT technique. Biomass Bioenerg. 21, 81-90.

Vervaeke, P., Luyssaert, S., Mertens, J., Meers, E., Tack, F.M.G., Lust, N., 2003. Phytoremediation prospects of willow stands on contaminated sediment: a field trial. Environ. Pollut. 126, 275-282.

Vervaeke, P., Mertens, J., Lust, N., Tack, F.M.G., 2004. Seasonal changes of heavy metals in biomass compartments of Salix stands growing on contaminated dredged sediment: potentials and limitations for phytoremediation. Environ. Sci. Technol., submitted.

VLAREBO, 1996. Besluit van de Vlaamse regering houdende vaststelling van het Vlaams reglement betreffende de bodemsanering. Belgisch Staatsblad, 27 maart 1996.

Watson, C., Pulford, I.D., Riddell-Black, D., 1999. Heavy metal toxicity responses of two willow varieties grown hydroponically: development of a tolerance screening test. Environ. Geochem. Health 21, 359-364. 
Figure 1. $\mathrm{Zn}, \mathrm{Mn}, \mathrm{Cd}$ and $\mathrm{Cu}$ concentrations ( $\left.\mathrm{mg} \mathrm{kg}^{-1} \mathrm{DW}\right)$ in roots, stems and leaves for 2 clones (AAGE: S. viminalis clone "Aage", B.Rood: S. fragilis clone "Belgisch Rood") as function of aqua regia extractable soil concentrations ( $\mathrm{mg} \mathrm{kg}^{-1}$ dry soil) in a greenhouse experiment with 6 sediment-derived soils (S1-S6, see Table 1)

Figure 2. $\mathrm{Cd}, \mathrm{Cu}$ and $\mathrm{Zn}$ concentrations $\left(\mathrm{mg} \mathrm{kg}^{-1} \mathrm{DW}\right)$ in roots, stems and leaves as function of pore water concentrations for 2 clones (AAGE: S. viminalis clone "Aage", B.Rood: $S$. fragilis clone "Belgisch Rood")

Figure 3. $\mathrm{Fe}, \mathrm{Cr}, \mathrm{Pb}$ and $\mathrm{Ni}$ concentrations in roots, stems and leaves for 2 clones (AAGE: $S$. viminalis clone "Aage", B.Rood: S. fragilis clone "Belgisch Rood") as function of aqua regia extractable soil concentrations in a greenhouse experiment with 6 sediment-derived soils (S1S6, see Table 1)

Figure 4. Bioconcentration factors (BCF) for (a) $\mathrm{Cd}$ and (b) $\mathrm{Zn}$ in the leaves as function of aqua regia extractable soil $\mathrm{Cd}$ and $\mathrm{Zn}$ concentrations for 2 clones (triangles: $S$. fragilis clone "Belgisch Rood", squares: AAGE: S. viminalis clone "Aage") 
Table 1. Properties for the soils used in the greenhouse experiment. Soil metal contents are aqua regia extractable contents. Values in parentheses denote standard deviations for 4 replicates (EC: electrical conductivity, OC: organic carbon)

\begin{tabular}{|c|c|c|c|c|c|c|c|}
\hline & & s1 & S2 & S3 & S4 & S5 & S6 \\
\hline $\mathbf{C d}$ & $\mathrm{mg} \mathrm{kg}^{-1}$ dry soil & $0.9(0.02)$ & $14(0.1)$ & $13.1(0.4)$ & $22.2(0.5)$ & $23.2(0.4)$ & $41.4(0.6)$ \\
\hline $\mathrm{Cr}$ & $\mathrm{mg} \mathrm{kg}^{-1}$ dry soil & $65(1)$ & $481(4)$ & $246(6)$ & $1287(31)$ & $1914(23)$ & $779(9)$ \\
\hline $\mathrm{Cu}$ & $\mathrm{mg} \mathrm{kg}^{-1}$ dry soil & $54(1)$ & $143(3)$ & $145(3)$ & $106(2)$ & $166(1)$ & $99(1)$ \\
\hline $\mathrm{Ni}$ & $\mathrm{mg} \mathrm{kg}^{-1}$ dry soil & $34(0.8)$ & $37(0.4)$ & $46(1.0)$ & $40(1.1)$ & $40(0.5)$ & $35(0.3)$ \\
\hline $\mathrm{Pb}$ & $\mathrm{mg} \mathrm{kg}^{-1}$ dry soil & $49(1)$ & $134(1)$ & $223(6)$ & $655(20)$ & $334(21)$ & $286(4)$ \\
\hline $\mathrm{Zn}$ & $\mathrm{mg} \mathrm{kg}^{-1}$ dry soil & $188(8)$ & $966(51)$ & $1131(58)$ & 2175 (59) & $2422(60)$ & 2087 (37) \\
\hline Mn & $\mathrm{mg} \mathrm{kg}^{-1}$ dry soil & $372(6)$ & $803(3)$ & $292(6)$ & $697(26)$ & $370(6)$ & $349(3)$ \\
\hline $\mathrm{Fe}$ & $\mathrm{g} \mathrm{kg}^{-1}$ dry soil & $38(0.1)$ & $31.1(0.1)$ & $25.9(0.1)$ & $34.1(0.1)$ & $28.2(0.1)$ & $32.2(0.1)$ \\
\hline clay & $\%$ & $47(8)$ & $41(2)$ & $57(7)$ & $45(2)$ & $37(3)$ & $39(2)$ \\
\hline silt & $\%$ & $51(6)$ & $56(2)$ & $41(4)$ & $53(3)$ & $52(4)$ & $57(1)$ \\
\hline sand & $\%$ & $2(2)$ & $12(3)$ & $2(3)$ & $3(3)$ & $11(2)$ & $5(2)$ \\
\hline $\mathbf{N}$ & $\%$ & $0.41(0.05)$ & $0.54(0.13)$ & $0.49(0.07)$ & $0.49(0.03)$ & $0.59(0.4)$ & $0.43(0.02)$ \\
\hline $\mathrm{CaCO}_{3}$ & $\%$ & $5.1(1)$ & $11.5(0.7)$ & $8.2(0.8)$ & $10.1(0.2)$ & $7.7(1)$ & $5.1(0.1)$ \\
\hline OC & $\%$ & $3.7(0.4)$ & $4.9(0.9)$ & $5.2(0.4)$ & $5.1(0.4)$ & $6.1(0.9)$ & $5.4(0.2)$ \\
\hline $\mathrm{pH}-\mathrm{H}_{2} \mathrm{O}$ & & $7.2(0.1)$ & $7.5(0.05)$ & $7.3(0.1)$ & $7.3(0.05)$ & $7.3(0.1)$ & $7.5(0.05)$ \\
\hline $\mathrm{pH}-\mathrm{CaCl}_{2}$ & & $7.5(0.1)$ & $7.1(0.05)$ & $7.3(0.1)$ & $6.8(0.1)$ & $7.1(0.1)$ & $7.2(0.05)$ \\
\hline EC & $\mu \mathrm{S} \mathrm{cm}{ }^{-1}$ & $2369(247)$ & $286(51)$ & $1763(402)$ & $238(29)$ & $1017(61)$ & $253(13)$ \\
\hline
\end{tabular}


Table 2. Growth parameters for 2 clones for the 6 soils used in the greenhouse experiment, with standard deviations for 6 replicates in parentheses (B.Rood: S. fragilis clone "Belgisch Rood" and AAGE: S. viminalis clone "Aage")

\begin{tabular}{cccccc} 
Soil & Clone & Number of leaves & Length first shoot $\mathbf{( c m )}$ & Total shoot length $(\mathbf{c m})$ & Root biomass (g DW) \\
\hline S1 & AAGE & $39.2(11.6)$ & $49.4(12.5)$ & $63.3(25)$ & $0.42(0.2)$ \\
& B.Rood & $49(19.4)$ & $23.7(17)$ & $86.3(24.8)$ & $1.0(0.31)$ \\
S2 & AAGE & $38.2(13)$ & $20.4(9.1)$ & $46.2(26.1)$ & $0.34(0.2)$ \\
& B.Rood & $33.7(11.3)$ & $31(13.4)$ & $52.3(17.9)$ & $0.48(0.3)$ \\
S3 & AAGE & $35.6(15.1)$ & $45.4(12)$ & $60.2(21.5)$ & $0.68(0.55)$ \\
& B.Rood & $46(14.9)$ & $38.2(17.2)$ & $72.4(19.1)$ & $0.73(0.42)$ \\
S4 & AAGE & $45.5(18.7)$ & $38(17.6)$ & $57.7(21.7)$ & $0.62(0.41)$ \\
& B.Rood & $48(21.4)$ & $32.2(14.2)$ & $91.3(30)$ & $1.24(0.27)$ \\
S5 & AAGE & $38.2(6.5)$ & $37.2(3.1)$ & $57.1(13.6)$ & $0.57(0.15)$ \\
& B.Rood & $35.3(13.6)$ & $33.8(12.7)$ & $74.7(20.5)$ & $0.75(0.54)$ \\
\multirow{2}{*}{ S6 } & AAGE & $44.3(16.9)$ & $22.8(13.6)$ & $51.4(24.7)$ & $0.53(0.32)$ \\
& B.Rood & $42(9.2)$ & $27.3(12.4)$ & $66.7(21.1)$ & $0.76(0.29)$ \\
\hline
\end{tabular}


Table 3. Concentrations ( $\mathrm{mg} \mathrm{kg}^{-1} \mathrm{DW}$ ) in plant tissue compartments for 2 clones, averaged for the 6 soils used in the greenhouse experiment (B.Rood: S. fragilis clone "Belgisch Rood" and AAGE: $S$. viminalis clone "Aage")

\begin{tabular}{|c|c|c|c|c|c|c|}
\hline & $\begin{array}{c}\text { AAGE } \\
\text { root }\end{array}$ & $\begin{array}{c}\text { AAGE } \\
\text { stem } \\
\end{array}$ & $\begin{array}{l}\text { AAGE } \\
\text { leaves }\end{array}$ & $\begin{array}{c}\text { B.Rood } \\
\text { root }\end{array}$ & $\begin{array}{l}\text { B.Rood } \\
\text { stem }\end{array}$ & $\begin{array}{l}\text { B.Rood } \\
\text { leaves }\end{array}$ \\
\hline $\mathrm{Fe}$ & 1695 & 66 & 159 & 1074 & 45 & 146 \\
\hline $\mathrm{Cu}$ & 170.3 & 11.6 & 10.1 & 157.5 & 10.0 & 11.1 \\
\hline $\mathrm{Cr}$ & 50.5 & 2.1 & 2.5 & 31.7 & 2.3 & 5.4 \\
\hline $\mathrm{Ni}$ & 9.1 & 2.5 & 2.9 & 9.5 & 2.7 & 6.0 \\
\hline Mn & 44.4 & 12.3 & 62.4 & 29.4 & 18.9 & 201.7 \\
\hline $\mathrm{Pb}$ & 13.4 & 1.1 & 2.8 & 11.5 & 1.3 & 3.5 \\
\hline
\end{tabular}


Figure 1.
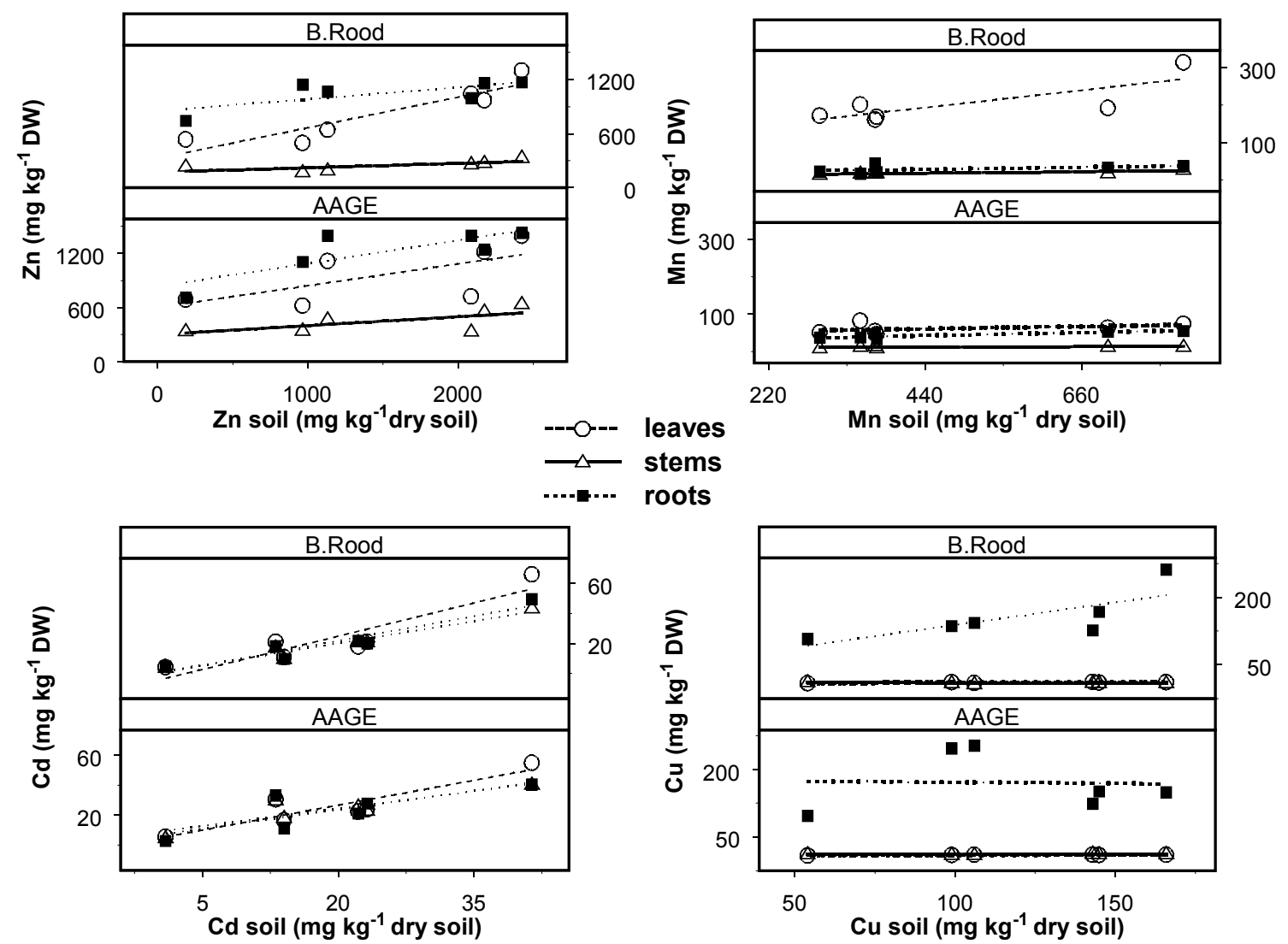
Figure 2.
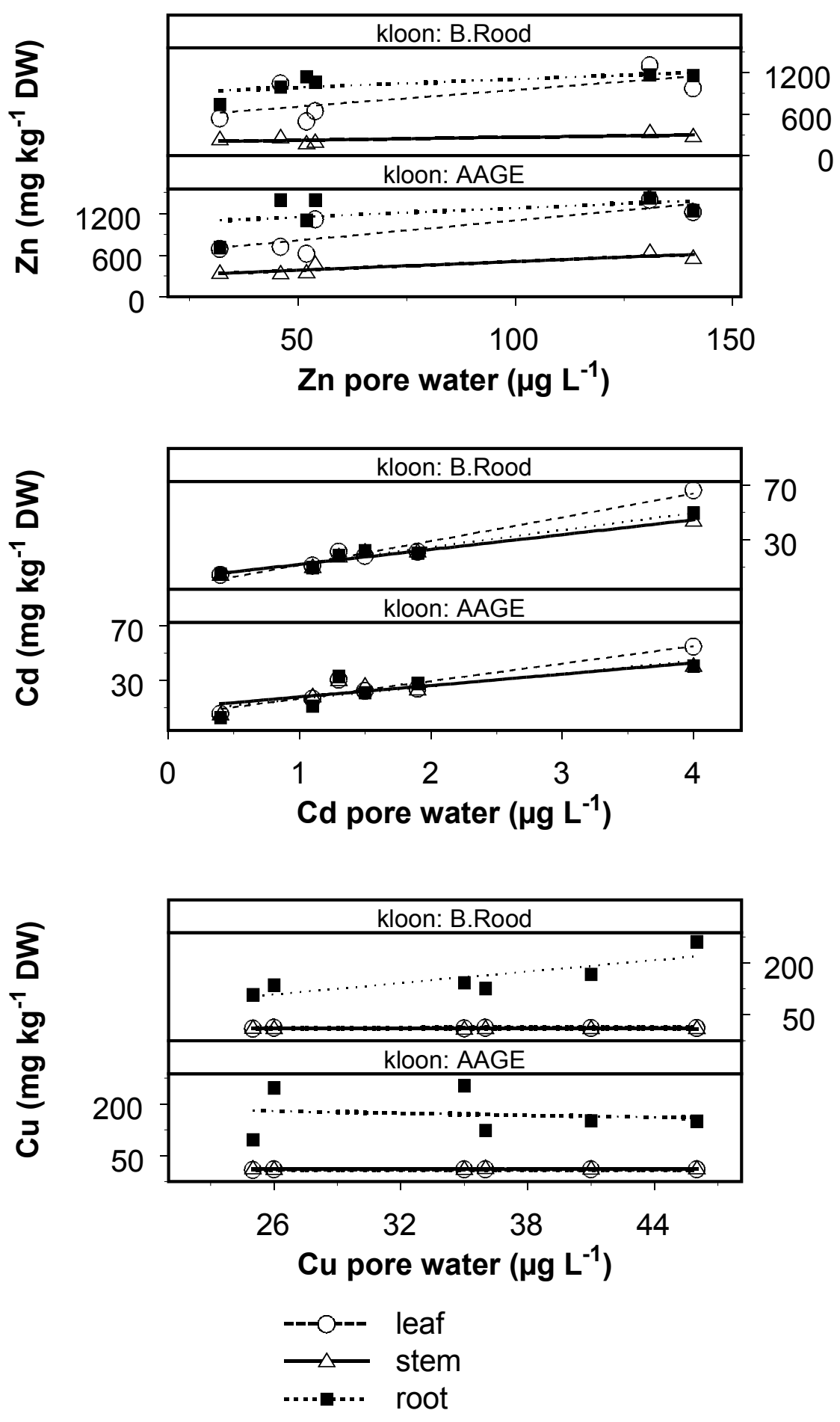


\section{Figure 3.}
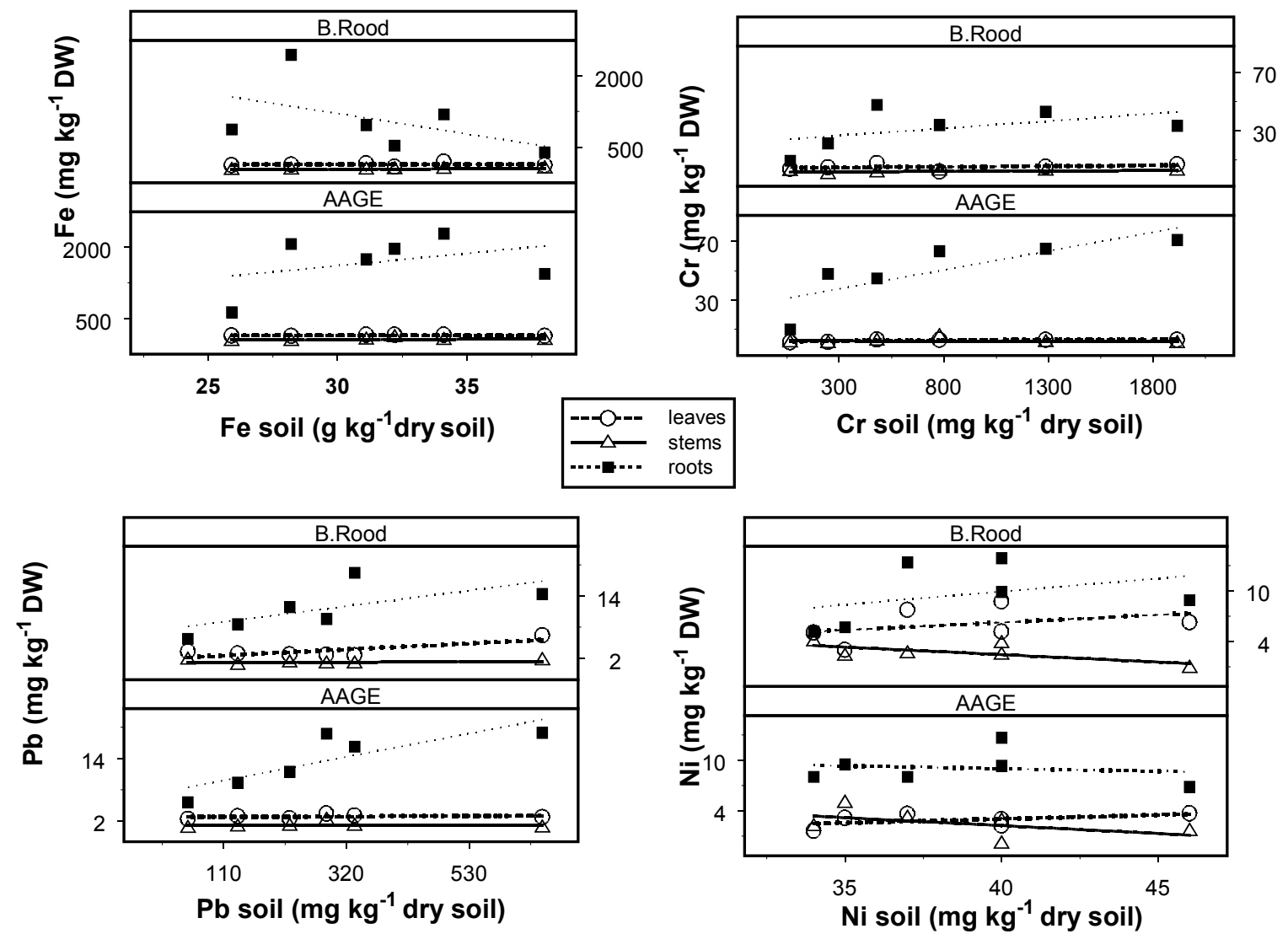
Figure 4.
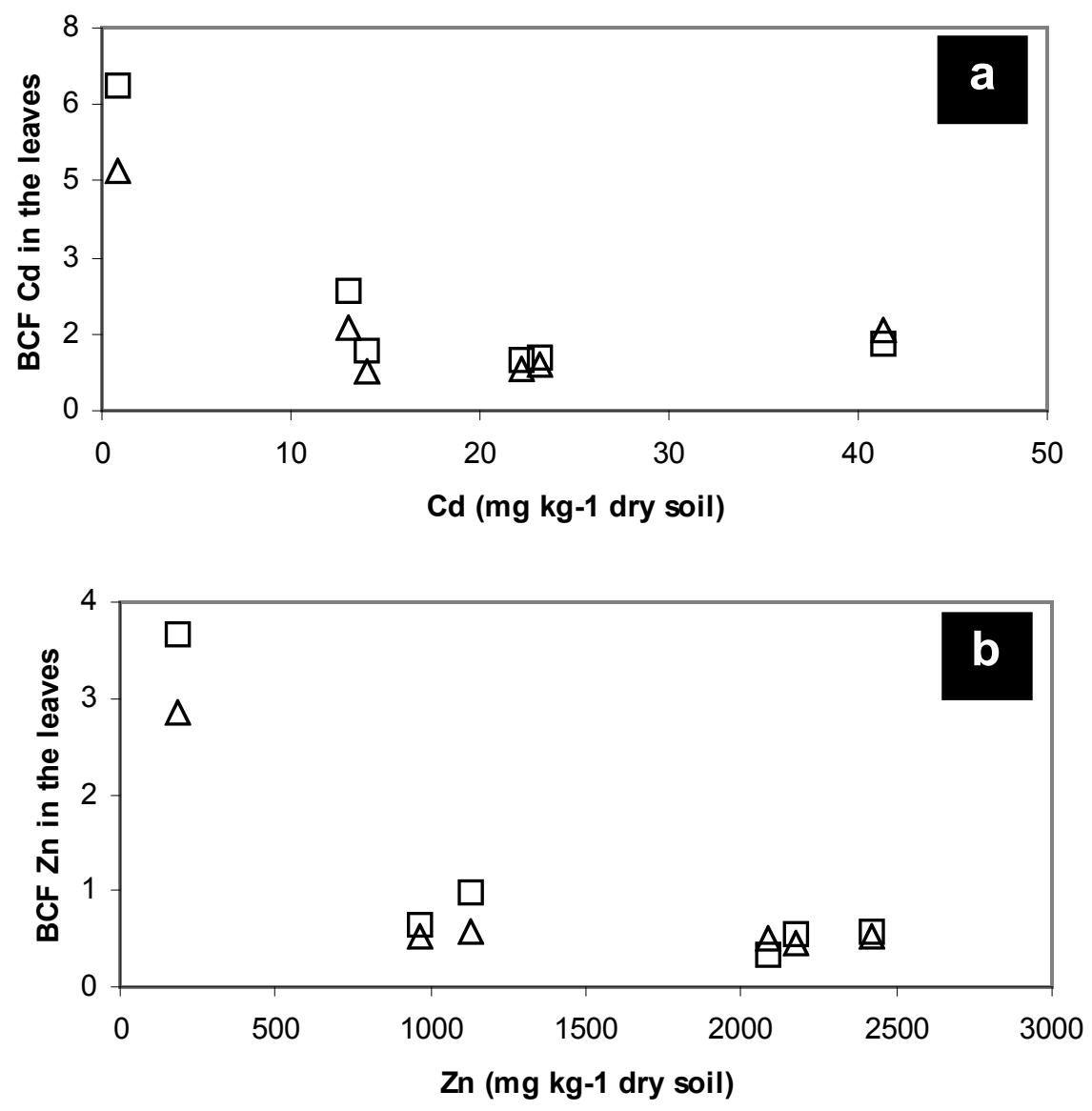